\title{
Peran Broadband Learning Center dalam community development
}

\section{The role of Broadband Learning Center for community development}

\author{
Putu Aditya Ferdian Ariawantara \\ Departemen Administrasi, FISIP, Universitas Airlangga \\ Jalan Airlangga 4-6 Surabaya 60286, Indonesia \\ E-mail: ilyapsasternak@gmail.com
}

\begin{abstract}
Answering the need of non-formal education or courses that reach all levels of society in the field of information and communication technology (ICT), the Government of Surabaya through the Department of Communications and Information Technology has developed Broadband Learning Center (BLC). BLC plays significant role in community development Surabaya since they provide media for public to choose training program which they can register independently or in groups training for free. This study aims to describe the framework in BLC as the implementation of e-governance performed by Government of Surabaya and to explore the role of BLC in community development process in achieving e-governance. The method used by researcher is qualitative approach with descriptive research type, focusing on Department of Communications and Information Technology, BLC Rumah Bahasa, BLC Taman Prestasi and BLC Taman Flora. This research reveals that BLC is facilitated with openness service to IT and various courses to enhance capacity and capability to utilize computer, and to increase public participation in using IT based program.
\end{abstract}

Keywords: e-governance, community development, implementation, training, information, communication, technology

\begin{abstract}
Abstrak
Dalam menjawab kebutuhan akan tersedianya pendidikan non-formal atau kursus yang bisa melayami seluruh lapisan masyarakat dalam bidang teknologi informasi dan komunikasi (TIK), Pemerintah Kota Surabaya melalui Dinas Komunikasi dan Informatika memiliki program Broadband Learning Center (BLC). BLC berperan dalam community development yang ada di Kota Surabaya, karena masyarakat bisa memilih pelatihan program apa yang dibutuhkan dan bisa mendaftarkan pelatihan baik mandiri maupun berkelompok secara gratis. Penelitian ini bertujuan untuk mendeskripsikan framework dalam BLC sebagai implementasi dari e-governance yang dilakukan oleh Pemerintah Kota Surabaya; dan mendeskripsikan peranan BLC dalam community development di Kota Surabaya, sehingga dapat mewujudkan e-governance pada Pemerintah Kota Surabaya. Metode penelitian yang digunakan oleh peneliti adalah pendekatan kualitatif dengan tipe penelitian bersifat deskriptif, dengan fokus penelitian pada Dinas Komunikasi dan Informatika, BLC Rumah Bahasa, BLC Taman Prestasi, dan BLC Taman Flora. Hasil dalam penelitian ini adalah program BLC masyarakat diberikan pelayanan keterbukaan atas TIK, diberikan pelatihan untuk meningkatkan kapasitas dan kemampuannya menggunakan komputer, serta dapat mendorong pemahaman dan partisipasi masyarakat dalam program-program berbasiskan IT yang digalakkan oleh Pemerintah Kota Surabaya.
\end{abstract}

Kata kunci : e-governance, community development, implementasi, pelatihan, informasi, komunikasi, teknologi

\section{Pendahuluan}

Perkembangan teknologi informasi pada era globalisasi sangat pesat. Ditandai dengan hilangnya "batasan" wilayah antar negara, bahkan sampai pada tingkat desa yang memungkinkan memiliki jaringan dengan desa lain pada negara lain. Dalam membentuk jaringan baik untuk kebutuhan bisnis, pendidikan, maupun pelayanan sosial lainnya masyarakat dituntut untuk dapat mengakses dan memanfaatkan teknologi informasi dan komunikasi dengan optimal.

Pada desa global, anak-anak dan remaja -dengan praktik yang mereka lakukan sendiri dan pilihan konsumen- berada di garda depan dalam perkembangan penggunaan teknologi informasi dan komunikasi (TIK), yang yang memiliki implikasi positif bagi masa depan masyarakat. Sejumlah pemikir dari ideologi yang beragam menunjukkan bahwa anak-anak dan remaja dapat bertindak sebagai "intelektual oposisi" dan "gerilyawan semiotik" dari jaman internet (Tapscott 1998). 
Kemajuan teknologi ini juga meningkatkan indikator pendidikan, di mana dulu hanya diorientasikan untuk mengentaskan buta aksara, tetapi sekarang ditambah lagi dengan kemampuan memanfaatkan komputer dan internet. Pekerjaan pemerintah untuk mengentaskan penduduk yang buta huruf dalam MEA 2015 masih belum terselesaikan, ditambah lagi tuntutan agar masyarakat mampu mengoperasionalkan komputer dan internet sesuai dengan kebutuhan pada masing-masing sektor.

Selain komputer, globalisasi ditandai dengan penggunaan internet secara masif. Konektivitas internet sudah bergeser, dari yang tadinya masuk ke dalam kebutuhan tersier sekarang masuk dalam kategori kebutuhan sekunder. Riset yang dilakukan oleh APJII (Asosiasi Penyelenggara Jasa Internet Indonesia) melakukan resume terhadap lanskap pengguna teknologi di tahun 2014 mengemukakan data bahwa $84 \%$ dari responden mengakses internet setiap harinya (baik untuk kegiatan kantor, pendidikan, jual-beli, atau menyalurkan hobi surfing di dunia maya), dan kebanyakan responden mengakses internet antara 3 hingga 5 jam per hari. Dari penelitian tersebut juga dikemukakan terkait perihal yang dilakukan masyarakat Indonesia dalam menggunakan internet. Sebagian besar yaitu sebanyak $87,4 \%$ internet digunakan untuk media sosial, selanjutnya sebanyak 68,7\% digunakan untuk mencari informasi/sumber bacaan/browsing, pada urutan ketiga yaitu 59,9\% untuk mengirim pesan. Sedangkan persentase paling kecil adalah untuk media pembelajaran jarak jauh $(0,8 \%)$.

Komputer dan internet harus dimanfaatkan secara optimal untuk meningkatkan kapasitas individu masyarakat. Globalisasi seiring dengan perubahan paradigma baru dalam administrasi publik, yaitu electronic governance (e-governance) -mendorong semua pelayanan publik untuk bisa transparan dan akuntabel dengan memanfaatkan TIK, sehingga untuk masyarakat yang ingin mengakses pelayanan publik atau dimasa datang bisa dilakukan $e$-voting untuk pemilu- didorong untuk bisa menggunakan komputer dan mengakses internet.

Surabaya sebagai kota pelopor dalam pengadaan barang dan jasa melalui e-procurement, terus meningkatkan kapasitasnya dalam e-governance. Setelah menyentuh sisi birokrasi pemerintahan, $e$ governance juga dimanfaatkan untuk meningkatkan kapasitas masyarakat agar bisa menggunakan komputer dan internet sesuai dengan bidangnya masing-masing. Terobosan yang dilakukan Pemerintah Kota Surabaya ini disebut BLC (Broadband Learning Center). Pembangunan BLC dilatarbelakangi sebagai upaya untuk mewujudkan Surabaya Multi Media City (SMMC), Pemerintah Kota Surabaya melalui Dinas Komunikasi dan Informatika Kota Surabaya bekerja sama dengan PT. Telkom Divre V Jawa Timur membangun sarana pembelajaran telematika yang berlokasi di beberapa tempat di Surabaya, sebagai upaya untuk mewujudkan tujuan nasional, khususnya dalam rangka mencerdaskan kehidupan bangsa dan mendorong tumbuhnya berbagai inovasi dalam sistem pendidikan. Perubahan besar yang terjadi dalam lingkungan global mengharuskan pemerintah untuk mengembangkan sistem pendidikan yang lebih terbuka, luwes, berkualitas dan dapat diakses oleh siapa saja yang memerlukan, tanpa memandang usia, jenis kelamin, lokasi, kondisi sosial-ekonomi, maupun pengalaman pendidikan sebelumnya. BLC diharapkan mampu membuat warga Surabaya dapat dengan mudah mengakses perangkat TIK yang disediakan.

\section{Metode Penelitian}

Penelitian ini menggunakan metode kualitatif, sehingga fokus utama penelitian adalah memperoleh pemahaman atas tindakan dan makna gejala sosial dalam sudut pandang subyek penelitian. Alasan peneliti menggunakan metode penelitian kualitatif adalah sifat masalah yang diteliti, di mana penelitian ini berupaya mengungkap dan memahami sesuatu makna di balik fenomena dalam suatu konteks khusus. Pendekatan yang digunakan oleh peneliti adalah pendekatan kualitatif dengan tipe penelitian bersifat deskriptif, karena penelitian ini akan bertujuan untuk mengetahui framework dalam BLC sebagai implementasi dari e-governance yang dilakukan oleh Pemerintah Kota Surabaya dan mendeskripsikan peranan BLC dalam community development warga Kota Surabaya untuk bisa menggunakan komputer dan internet.

Tipe penelitian deskriptif ini mencoba menggambarkan fenomena yang terjadi. Dalam hal ini, peneliti mencoba memberikan gambaran sejelas mungkin mengenai Program BLC yang ada di Kota Surabaya 
dapat berperan dalam community development berdasarkan informasi yang didapat dari informan dan tidak bergantung pada pengukuran dengan angka.

Secara purposif penelitian dilakukan di Kota Surabaya, karena Pemerintah Kota Surabaya melalui Dinas Komunikasi dan Informatika memiliki Program BLC. Lokasi BLC yang diambil untuk dijadikan sebagai fokus penelitian terdapat pada tiga tempat, yaitu BLC Rumah Bahasa; BLC Taman Prestasi, dan BLC Taman Flora. Lokasi ini diambil karena dua alasan, pertama disarankan oleh pihak Dinas Komunikasi dan Informatika karena dianggap sebagai BLC yang peminatnya paling banyak. Kedua, adalah setelah dilakukan observasi pendahuluan pada ketiga lokasi ini dianggap cukup representatif sebagai perwakilan dari BLC lainnya yang tersebar diwilayah Kota Surabaya.

Data yang diperoleh terbagi atas dua jenis, yaitu data primer dari hasil indepth interview yang dilakukan dengan informan, dan data sekunder berupa profil dan data-data lain sebagai pendukung penelitian ini. Setelah data diperoleh kemudian dianalisis dengan tiga alur, yaitu: reduksi data, penyajian data dan penarikan kesimpulan. Dalam penelitian ini untuk memperoleh suatu keabsahan data maka derajat kepercayaan pemeriksaan data dilakukan dengan teknik triangulasi.

\section{Hasil Penelitian dan Pembahasan}

Sesuai dengan Undang-Undang Republik Indonesia tentang Informasi dan Transaksi Elektronik Nomor 11 Tahun 2008 disebutkan "Pemanfaatan Teknologi Informasi dan Transaksi Elektronik dilaksanakan dengan tujuan untuk: a) mencerdaskan kehidupan bangsa sebagai bagian dari masyarakat informasi dunia; b) mengembangkan perdagangan dan perekonomian nasional dalam rangka meningkatkan kesejahteraan masyarakat; c) meningkatkan efektivitas dan efisiensi pelayanan publik; d) membuka kesempatan seluas-luasnya kepada setiap orang untuk memajukan pemikiran dan kemampuan di bidang penggunaan dan pemanfaatan Teknologi Informasi seoptimal mungkin dan bertanggung jawab; dan e) memberikan rasa aman, keadilan, dan kepastian hukum bagi pengguna dan penyelenggara Teknologi Informasi" (Pasal 4). Sesuai dengan undang-undang tersebut, dalam konteks ini BLC di Kota Surabaya menjadi tonggak untuk mencerdaskan masyarakat dalam memanfaatkan TIK.

\section{Implementasi BLC sebagai e-governance}

Electronic government (e-government) adalah istilah generik untuk layanan berbasis website atau internet dari instansi pemerintah baik pusat maupun daerah, jika di Amerika konteksnya adalah negara bagian dan federal. Dalam e-government, pemerintah menggunakan TIK dan terutama internet untuk mendukung operasi pemerintah, melibatkan warga negara, dan menyediakan layanan pemerintah. Interaksi pemerintah dan warga negara terjadi dalam bentuk memperoleh informasi, pengajuan pelayanan, atau melakukan pembayaran dan sejumlah kegiatan lainnya melalui world wide web (WWW) (Sharma \& Gupta 2003, Sharma 2004, Sharma 2006).

Sebagian besar pemerintah telah mengambil inisiatif menawarkan layanan online. Namun, untuk potensi sesungguhnya dari e-government, pemerintah perlu melakukan restrukturisasi dan transformasi proses yang panjang dan berkelanjutan. Menurut Gartner, e-government melibatkan penggunaan TIK untuk mendukung operasi pemerintah dan memberikan layanan pemerintahan (Palvia \& Sharma 2007:1). Namun, e-government bahkan melangkah lebih jauh dan bertujuan untuk secara mendasar mengubah proses produksi di mana pelayanan publik dihasilkan dan disampaikan, sehingga mengubah seluruh rentang hubungan badan publik dengan warga negara, perusahaan dan pemerintah (Palvia \& Sharma 2007:1).

Melihat pada kemajuan e-government di Thailand berdasarkan studi yang dilakukan oleh Somnuk Keretho (2013) berfokus pada empat bidang utama, yaitu: 1) Interoperabilitas untuk berbagi data/informasi dan layanan di seluruh organisasi pemerintah, membantu untuk mencapai pengembangan layanan terpadu; 2) Struktur kelembagaan dan mekanisme pemerintahan untuk melakukan manajemen pengawasan tingkat tinggi dan pengawasan dalam pelaksanaan program $e$ - 
government; 3) Inovasi dalam pelayanan publik untuk embedding inovasi dalam desain dan pemberian layanan pemerintah termasuk penggunaan open source, crowd source dan community source approaches; dan 4) Rekayasa ulang dengan maksud untuk "doing more with less for more", menggabungkan layanan yang lebih baik dan biaya yang lebih rendah sementara berdampak lebih banyak pada masyarakat.

Electronic governance (e-governance), yang berarti 'pemerintahan elektronik' yang menggunakan teknologi informasi dan komunikasi (TIK) di berbagai tingkatan dari pemerintah dan sektor publik dan di luar badan pemerintah, untuk tujuan pemerintahan (Bedi K, Singh PJ, \& Srivastava S 2001, Holmes 2001, Okot-Uma 2000 dalam Palvia \& Sharma 2007:1). Menurut Keohane dan Nye (2000) dalam Palvia \& Sharma (2007:2), governance menggambarkan suatu proses dan lembaga, baik formal maupun informal, yang mendukung dan menahan kegiatan kolektif kelompok. Pemerintah adalah bagian yang bertindak dengan kewenangan dan menciptakan kewajiban formal. Governance mau tidak mau dilakukan secara eksklusif oleh pemerintah, perusahaan swasta, asosiasi perusahaan, lembaga swadaya masyarakat (LSM), dan asosiasi LSM yang terlibat di dalamnya, sering dalam hubungan dengan badan-badan pemerintah, untuk menciptakan pemerintahan; kadang-kadang tanpa otoritas pemerintah. Jelas, definisi ini menunjukkan bahwa e-governance tidak terbatas pada sektor publik saja, namun juga bisa dilakukan pada sektor bisnis (Good Corporate Governance/GCG) maupun pada badan LSM.

Beberapa penulis dan peneliti berpendapat bahwa e-government hanya merupakan subset dari $e$ governance. Menurut mereka, e-governance adalah suatu konsep yang lebih luas dari pada $e$ government dan mencakup penggunaan TIK oleh pemerintah dan masyarakat sipil untuk mendorong partisipasi yang lebih besar dari warga dalam pemerintahan lembaga-lembaga politik, misalnya, penggunaan internet oleh aktor politisi dan partai politik untuk mendapatkan data dari konstituen mereka secara cepat dan efisien, atau publikasi oleh organisasi masyarakat sipil yang biasanya bertentangan dengan kepentingan pemerintah (Palvia \& Sharma 2007:3). Hal ini jelas bahwa para akademisi mengalami kesulitan dalam menjelaskan mengenai e-government dan e-governance. Hal ini dapat disederhanakan seperti fokus e-government adalah pada konstituen dan pemangku kepentingan di luar organisasi, apakah itu pemerintah atau sektor publik, daerah, negara, atau tingkat nasional, internasional. Di sisi lain, e-governance berfokus pada administrasi dan manajemen dalam sebuah organisasi, apakah itu publik atau swasta, besar atau kecil. Berdasarkan klasifikasi ini, $e$ governance berfokus pada utilisasi internal informasi dan teknologi internet untuk mengelola sumber daya organisasi yaitu modal, manusia, material, mesin dan mengelola kebijakan dan prosedur (baik untuk sektor publik atau sektor swasta).

Untuk mewujudkan keinginan dan kebutuhan masyarakat Surabaya akan pentingnya sumber belajar dengan menggunakan media Teknologi Informasi dan Komunikasi maka Pemerintah Kota Surabaya bekerjasama dengan PT Telkom Indonesia membangun "Broadband Learning Center" (BLC) yang letaknya ada di masing-masing bagian wilayah Kota Surabaya, yaitu Surabaya Selatan (Wiyung, Karang Pilang, Putat Jaya, Kupang Gunung, Kedurus, Sawunggaling), Surabaya Utara (Bulak, Telecenter Ampel, Rusun Tamer 1, Rusun Tamer 2), Surabaya Timur (Taman Flora, Rusun Penjaringan Sari, Gunung Anyar, Mulyorejo, Wonorejo), Surabaya Barat (Klakah Rejo, Sememi, Simomulyo, Made), dan Surabaya Pusat (Taman Prestasi, Rumah Bahasa, Rusun Grudo, Rusun Urip Sumoharjo).

BLC tersebut dibangun sebagai pusat sumber belajar untuk mewujudkan kepedulian akan pentingnya teknologi informasi dan sebagai upaya percepatan menuju Surabaya Cyber City, dan mendukung $e$ government di Kota Surabaya. Broadband Learning Center (BLC) merupakan pusat sumber belajar dan media atau sarana pendukung untuk mempelajari dunia internet maupun mempelajari dunia teknologi dan informasi misalnya pengetikan dengan menggunakan komputer, membuat presentasi, membuat desain gambar, dan pelatihan-pelatihan lain dengan media komputer yang berguna bagi masyarakat. Sebagai suatu implementasi dari e-governance, BLC memiliki tingkat keberhasilan yang cukup tinggi. Keberhasilan implementasi kebijakan ditentukan oleh lingkungan politik, administrasi, ekonomi, teknologi, sosial dan budaya yang kondusif (Grindle 1980). Selain implementasi kebijakan 
dipengaruhi oleh lingkungan Grindle (1980:9) mengemukakan bahwa keberhasilan implementasi kebijakan ditentukan oleh content of implementation dan context of implementation. Content of implementation mencakup kepentingan yang terpengaruhi oleh kebijakan; jenis manfaat yang dihasilkan; derajat perubahan yang diinginkan; kedudukan pembuat kebijakan; siapa pelaksana program; dan sumber daya yang dikerahkan. Context of implementation mencakup kekuasaan, kepentingan dan strategi aktor yang terlibat; karakteristik lembaga dan penguasa; dan kepatuhan dan daya tanggap.

Kelompok sasaran dalam BLC melingkupi segala profesi, antara lain adalah: a) Masyarakat umum baik perorangan maupun kelompok; b) Pelajar (SD, SMP, SMA, Mahasiswa); c) Pelaku Usaha (kelompok pelaku usaha mikro, kecil, dan menengah); d) KSM (Kelompok Swasembada Masyarakat); dan e) Kelompok Sosial (PKK, Karang Taruna, Dasa Wisma, Kader Lingkungan, Kader Ekonomi, Kader PAUD, dan kelompok sosial lainnya).

BLC terealisasi hampir di seluruh Kelurahan se kota Surabaya, program BLC ini selain sebagai upaya memacu penetrasi dan pemanfaatan TIK dan internet, juga sebagai bagian dari skenario besar yang dirancang oleh PT. Telkom untuk membangun Indonesia broadband yang disediakan pada BLC juga bertujuan memberikan pemahaman tentang penggunaan akses internet yang sehat. Pembangunan BLC di public area meliputi taman-taman kota dan di Surabaya sendiri telah banyak tersebar BLC yang relatif mudah dijangkau masyarakat luas, diantaranya Taman Bungkul, Taman Flora kebun Bibit dan Taman Prestasi, Telkom meyakini dengan kemudahan jangkauan untuk akses internet, kelak mampu meningkatkan partisipasi masyarakat terhadap program-program pembangunan di Surabaya. BLC merupakan fasilitas pembelajaran berbasis TIK dan internet yang dapat dimanfaatkan oleh masyarakat Kota Surabaya secara gratis. BLC hadir di lokasi-lokasi yang dekat dengan ruang publik, lokasinya berada di taman kota dan rumah susun (rusun), sehingga mudah diakses oleh masyarakat. BLC dikelola oleh Dinas Komunikasi dan Informatika Kota Surabaya. Pada tahun 2014 tercatat BLC telah didirikan di enam lokasi yaitu, Rusunawa Penjaringan Sari, Taman Prestasi, Taman Flora, Rusunawa Tanah Merah, Kelurahan Made, dan Rusunawa Urip Sumoharjo.

Broadband Learning Center memiliki materi-materi yang diberikan dalam setiap pelatihannya, antara lain :

Tabel 1.

Paket dan materi pelatihan BLC Surabaya selama 22 pertemuan

\begin{tabular}{llc}
\multicolumn{1}{c}{ Paket } & \multicolumn{1}{c}{ Materi } & Pertemuan \\
\hline Aplikasi Perkantoran & $\begin{array}{l}\text { Kingsoft Office Writer } \\
\text { Kingsoft Office Spreedsheet } \\
\text { Kingsoft Office Presentation } \\
\text { GiMP }\end{array}$ & $22 \times$ Pertemuan \\
Desain Grafis & $\begin{array}{l}\text { Inkscape } \\
\text { Internet, Blog dan Social Network }\end{array}$ & $22 \times$ Pertemuan \\
\hline Internet Bisnis Online & Intemuan
\end{tabular}

Sumber: data sekunder BLC Surabaya

Selain paket pelatihan dengan 22 kali pertemuan tersebut, ada juga pelatihan atau materi singkat supaya peserta dapat memahami materi secara umum, di antaranya adalah:

Tabel 2.

Paket dan materi pelatihan BLC Surabaya selama 5 pertemuan

\begin{tabular}{lll}
\hline Paket & Materi & Pertemuan \\
\hline Paket Singkat UKM & Design dan Internet & 5x Pertemuan \\
Paket Singkat Aplikasi Perkantoran & Kingsoft Office Writer & 5x Pertemuan \\
Paket Singkat Desain Grafis & Inkscape dan GIMP & $5 x$ Pertemuan \\
Paket Singkat Internet & Internet & $5 x$ Pertemuan \\
\hline
\end{tabular}

Sumber: data sekunder BLC Surabaya 
PT. Telkom yang bekerja sama dengan Pemerintah Kota Surabaya melalui Dinas Komunikasi dan Informatika membangun BLC dengan tujuan agar warga Kota Surabaya melek teknologi informasi. Ini merupakan salah satu upaya percepatan menuju Surabaya Cyber City. Cyber city merupakan salah satu konsep kota modern berbasis teknologi informasi yang kini telah banyak diterapkan di sejumlah kota besar di seluruh dunia. Ini adalah konsekuensi logis dari meningkatnya perkembangan teknologi sereta kebutuhan masyarakat yang ingin mengakses informasi dan berkomunikasi dengan mudah, murah dan cepat. Tujuan BLC untuk mewujudkan Surabaya Multi Media City (SMMC) dengan membangun sarana pembelajaran telematika yang berlokasi di beberapa tempat di Surabaya untuk mewujudkan tujuan nasional, khususnya dalam rangka mencerdaskan kehidupan bangsa dan mendorong tumbuhnya berbagai inovasi dalam sistem pendidikan. Sasaran sebagai SMMC antara lain adalah: 1) Surabaya Broadband Government and Education (B-GovEd) Wahana pelatihan pemanfaatan TIK secara selektif; 2) Surabaya pelajar SD, SLTP, dan SLTA di Kota Surabaya. Broadband Citizen bagi UKM, Layanan Free Hot Spot dan Community; dan 3) Informasi Surabaya Government di beberapa lokasi layanan informasi dan media pembelajaran telematika yang telah disepakati.

Untuk memperluas pelayanan yang ada di BLC, maka Pemerintah Kota Surabaya mendirikan BLC pada lokasi-lokasi yang strategis dan dapat dijangkau oleh masyarakat di antaranya dijabarkan seperti pada tabel 3:

Tabel 3.

Lokasi BLC pemerintah Kota Surabaya

\begin{tabular}{llll}
\hline No & \multicolumn{1}{c}{ EXISTING LOCATION } & No & \multicolumn{1}{c}{ EXISTING LOCATION } \\
\hline 1 & Rumah Bahasa & 15 & Kelurahan Ujung \\
2 & Kecamatan Bulak & 16 & Klakah Rejo \\
3 & Kecamatan Gunung Anyar & 17 & Kupang Gunung \\
4 & Kecamatan Karang Pilang & 18 & Rumah Susun Grudo \\
5 & Kecamatan Mulyorejo & 19 & Rumah Susun Penjaringansari \\
6 & Kecamatan Wiyung & 20 & Rumah Susun Romokalisari \\
7 & Kecamatan Pakal & 21 & Rumah Susun Tanah Merah I \\
8 & Kelurahan Dukuh Menanggal & 22 & Rumah Susun Tanah Merah II \\
9 & Kelurahan Kedurus & 23 & Rumah Susun Urip Sumoharjo \\
10 & Kelurahan Made & 24 & Sawunggaling \\
11 & Kelurahan Putat Jaya & 25 & Taman Flora \\
12 & Kelurahan Sememi & 26 & Taman Prestasi \\
13 & Kelurahan Simomulyo & 27 & Telecenter Ampel \\
14 & Kelurahan Wonorejo Rungkut & 28 & Griyo Keputih \\
\hline Sum
\end{tabular}

Sumber: data sekunder BLC Surabaya

BLC yang digagas Pemeirntah Kota Surabaya dalam mewujudkan masyarakat yang dapat menggunakan TIK sesuai dengan kebutuhannya disambut baik oleh lapisan-lapisan warga masyarakat. Hal ini ditunjukkan dalam gambar 1.

Dari gambar 1 dapat diketahui bahwa pengunjung BLC dari tahun 2014 (sebanyak 29.119 pengunjung) hingga tahun 2015 (36.853 pengunjung) masih didominasi oleh masyarakat yang masih duduk di bangku SD. Hal ini juga bisa dianalisis bahwa rasa ingin tahu dan belajar hal-hal yang baru lebih menonjol pada usia SD. Pada peringkat kedua adalah masyarakat yang duduk di bangku SLTP, yaitu sebanyak 6.981 pengunjung pada tahun 2014 dan 6.874 pengunjung pada tahun 2015. Data pengunjung di sini adalah sebagai pengunjung biasa, bukan orang-orang yang memanfaatkan pelatihan intensif dari BLC. Pengunjung bisa saja hanya sekedar browsing di internet untuk mencari informasi tertentu, membuka dan mengirim e-mail, membuka sosial media, atau memanfaatkan aplikasi office untuk memenuhi kebutuhan mereka saja. 


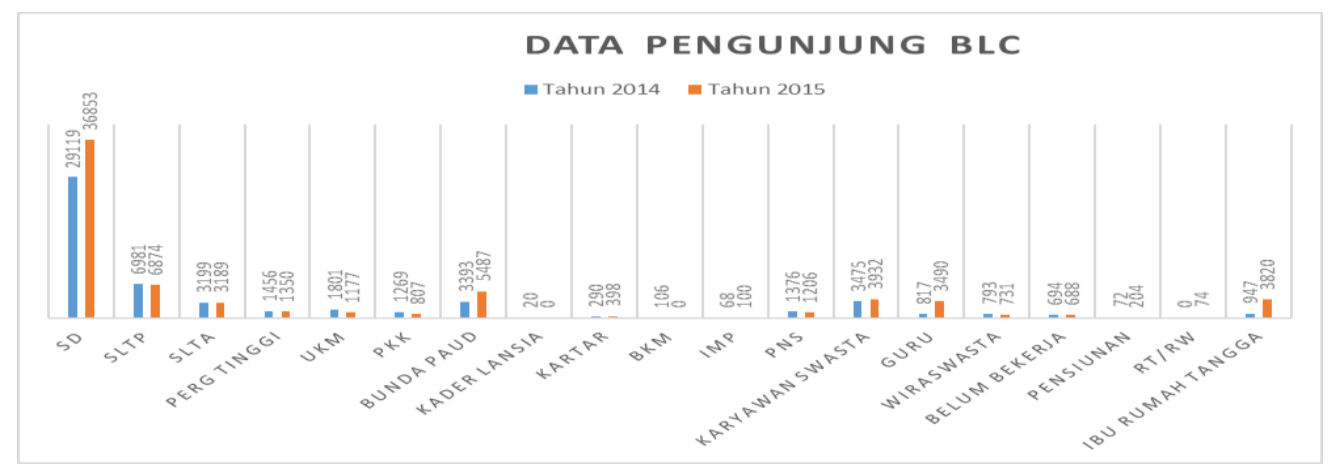

Gambar 1.

Data pengunjung BLC Surabaya

Sumber: data sekunder BLC Surabaya

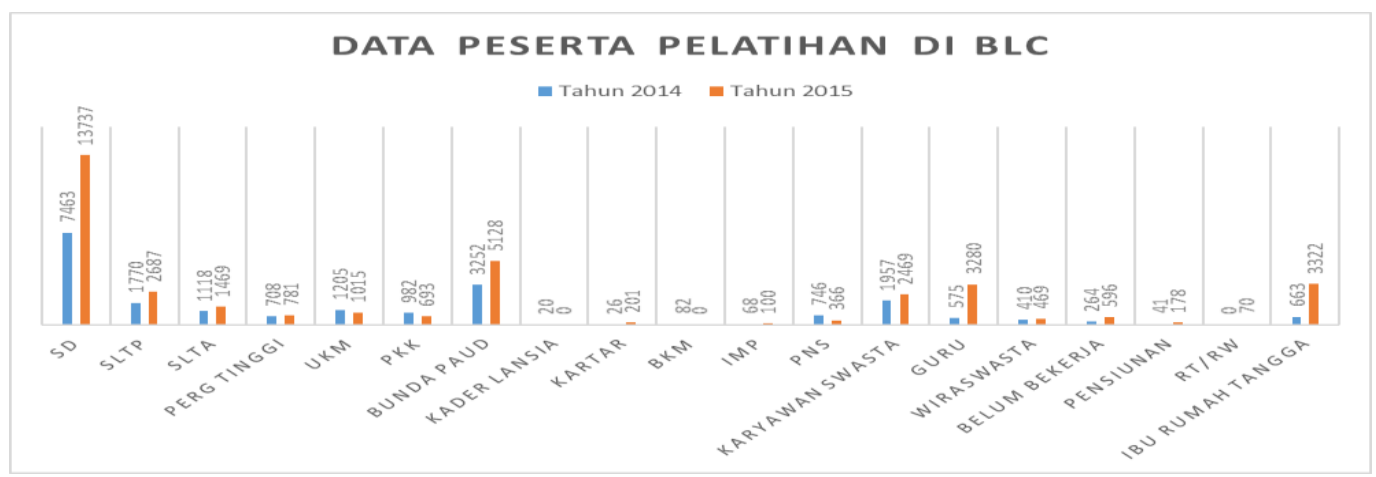

Gambar 2.

Data peserta pelatihan di BLC

Sumber: data sekunder BLC Surabaya

Gambar 2. menunjukkan data peserta yang mengikuti pelatihan secara intensif di BLC. Sama halnya seperti data pengunjung, peserta yang aktif mengikuti pelatihan didominasi oleh masyarakat yang duduk pada bangku SD. Dari tahun 2014 hingga tahun 2015 peningkatan animo anak-anak SD cukup siginifikan, yaitu meningkat sebanyak 6.274 peserta. Hal ini dikarenakan karena pelatihan di BLC tidak dipungut biaya dan ditambah lagi bisa mendapatkan sertifikat jika lulus ujian pada materi tertentu. Peserta pelatihan terbanyak berikutnya adalah Bunda PAUD yang jumlah pesertanya meningkat sebanyak 1.876 peserta dari tahun 2014 hingga 2015. Bunda Paud dituntut tidak hanya untuk menjalankan Paud di tingkat RT maupun RW, tetapi juga bisa meningkatkan pemahaman, keterampilan, dan wawasan mengenai administrasi perkantoran sederhana dengan memanfaatkan TIK, pencarian informasi mengenai pendidikan anak usia dini, kesehatan balita, sosial media, maupun bisnis dengan memanfaatkan toko online.

Peserta yang mengikuti pelatihan BLC yang jumlahnya mengalami kenaikan berikutnya adalah pada peserta dengan profesi Guru (naik sejumlah 2.705 peserta dari tahun 2014 hingga tahun 2015). Para Guru memanfaatkan BLC selain sebagai upgrading kemampuan mereka dibidang pemanfaatan software office yang mengunakan open source, juga banyak di antara mereka yang menginginkan mendapatkan sertifikasi apabila lulus pada salah satu materi pelatihan. Kelompok berikutnya yang mengalami peningkatan signifikan, yaitu pada kelompok Ibu Rumah Tangga (naik sejumlah 2.659 peserta dari tahun 2014 hingga tahun 2015). 


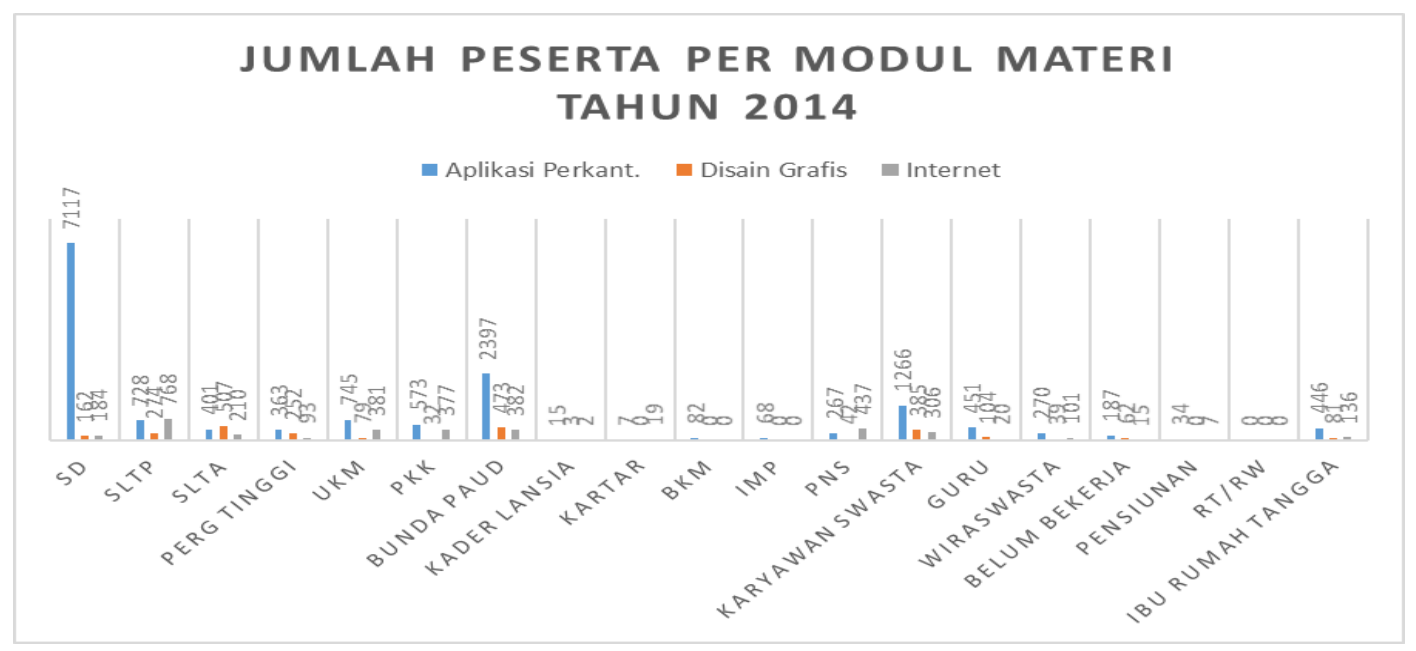

Gambar 3.

Jumlah Peserta per modul materi tahun 2014

Sumber: data sekunder BLC Surabaya

Jika melihat pada grafik Jumlah Peserta Per Modul Materi Tahun 2014, maka dapat diketahui bahwa sebagian besar peserta berminat pada materi aplikasi perkantoran (pengetikan, membuat presentasi, menghitung dalam tabel, dan sebagainya). Hal ini dikarenakan misalnya diambil contoh pada pengguna anak SD, mereka membutuhkan pelatihan aplikasi perkantoran untuk membuat tugas dalam bentuk tulisan atau makalah di komputer atau laptop. Begitu juga pada pengguna Bunda PAUD yang membutuhkan pelatihan aplikasi perkantoran untuk mengerjakan pelaporan administrasi kegiatan PAUD.

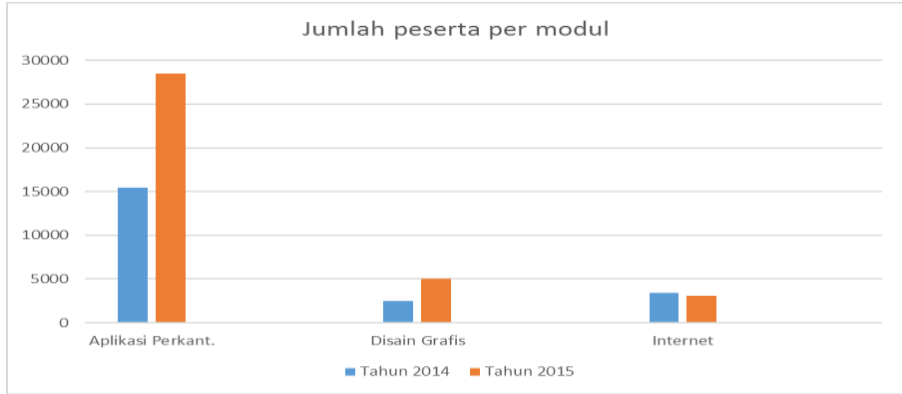

Gambar 4.

Jumlah peserta per modul 2014-2015

Sumber: data sekunder BLC Surabaya

Modul materi yang memiliki tingkat peminat yang tinggi adalah aplikasi perkantoran, hal ini dapat dilihat pada gambar 4 yang menunjukkan peningkatan signifikan terhadap jumlah peserta per modul. Hal ini membuktikan bahwa masih banyak masyarakat yang membutuhkan pelatihan aplikasi perkantoran, dan kegunaannya bisa langsung mereka praktekkan dalam lingkup pekerjaan sehari-hari.

Progam BLC Surabaya juga memberikan sertifikat sesuai dengan paket kursus yang diikuti oleh peserta secara gratis. Kelulusan yang paling banyak ada di BLC yang berlokasi di Taman Flora, Taman Prestasi, dan Kupang Gunung. Hal ini menunjukkan bahwa di beberapa lokasi BLC tersebut memiliki jumlah peserta yang paling banyak dibandingkan dengan lokasi BLC lainnya. Misalnya pada BLC di Taman Flora, memiliki tingkat kelulusan yang paling tinggi hal ini juga dipengaruhi oleh tingkat partisipasi masyarakat yang memanfaatkan fasilitas BLC di Taman Flora juga paling banyak. Pada BLC Taman Flora, pelatihan yang paling diminati adalah pelatihan internet untuk bisnis dan aplikasi perkantoran. Sejalan dengan itu, pada BLC Taman Prestasi pelatihan yang paling diminati adalah aplikasi perkantoran.

Dengan menggunakan definisi e-governance menurut UNESCO, yaitu penggunaan teknologi informasi dan komunikasi pada sektor publik dengan tujuan meningkatkan pelayanan informasi dan 
mendorong partisipasi masyarakat dalam proses pengambilan keputusan dan membuat pemerintah lebih akuntabel, transparan dan efektif, hal ini sudah diwujudkan dalam program BLC. Pada program tersebut masyarakat diberikan pelayanan keterbukaan atas TIK, diberikan pelatihan untuk meningkatkan kapasitas dan kemampuannya menggunakan komputer, serta mendorong partisipasi masyarakat dalam program-program berbasiskan IT yang digalakkan oleh Pemerintah Kota Surabaya, walaupun mungkin tujuan tersebut baru akan dirasakan minimal lima tahun kedepan.

Dalam e-governance juga melibatkan cara-cara baru untuk mengakses pendidikan, dalam BLC ini merupakan salah satu cara baru dalam pendidikan non formal dibidang TIK yang disediakan secara gratis oleh Pemerintah Kota Surabaya. Selain diberikan pelatihan secara cuma-cuma, masyarakat juga mendapatkan fasilitas antar jemput dengan mobil sebagai sarana dalam meningkatkan motivasi masyarakat dalam mengikuti pelatihan BLC. Sarana dan prasarana yang ada dalam BLC sudah cukup memadai, akan tetapi terdapat kendala yaitu spesifikasi komputer masih belum merata pada keseluruhan lokasi BLC. Hanya pada BLC Rumah Bahasa yang memiliki spesifikasi komputer lebih bagus, sehingga dapat menjalankan aplikasi desain grafis secara optimal.

Sosialisasi yang dilakukan oleh Dinas Komunikasi dan Informatika Pemerintah Kota Surabaya dianggap belum optimal, karena banyak warga masyarakat yang masih canggung untuk mengikuti pelatihan pada BLC. Sebagian masyarakat menganggap bahwa BLC yang letaknya di lokasi kecamatan tertentu hanya untuk masyarakat yang bertempat tinggal di sana, ada juga masyarakat yang menganggap bahwa BLC hanya untuk kalangan tertentu, sehingga warga enggan dalam mendaftar menjadi peserta atau sekedar mengikuti pelatihan on the spot, seperti disediakan pada BLC Rumah Bahasa.

Jika melihat content of implementation sebagai salah satu penentu keberhasilan implementasi kebijakan, maka dalam BLC ini memiliki kepentingan untuk mewujudkan Surabaya Multi Media City (SMMC) melalui media pendidikan yang inovatif dalam bidang TIK bagi warga Kota Surabaya. Hal ini tentu memiliki manfaat secara langsung bagi warga yang mengikuti pelatihan di BLC, selain mereka mendapatkan upgrading keilmuwan dibidang penggunaan aplikasi perkantoran dan internet yang dapat digunakan untuk menunjang kebutuhan sesuai dengan profesi masing-masing, mereka juga mendapatkan sertifikat sebagai pengakuan atas salah satu kemahiran aplikasi tertentu yang sudah mereka tempuh melalui pelatihan di BLC. Dalam context of implementation pada program BLC memiliki kepentingan dalam meningkatkan pemahaman masyarakat dibidang TIK, sehingga ketika pemerintah mengeluarkan program yang berkaitan dengan pelayanan publik yang menggunakan TIK seluruh warga masyarakat Kota Surabaya yang berkepentingan terhadap program tersebut dapat mengaksesnya dengan mudah. Untuk meningkatkan partisipasi warga masyarakat dalam memanfaatkan BLC pemerintah memberlakukannya secara gratis, dan diberikan sertifikat jika sudah menyelesaikan satu jenis materi pelatihan.

\section{BLC dalam community development}

Secara etimologis "community" berasal dari communitat yang berakar pada comunete atau common. Community mempunyai dua pengertian, yaitu (Ndraha 1990:49): a) Community sebagai kelompok sosial yang bertempat tinggal di lokasi tertentu, dan memiliki kebudayaan serta sejarah yang sama; dan b) Community sebagai satuan pemukiman yang terkecil, di atasnya ada kota kecil (town), dan di atas kota kecil ada kota atau kota besar (city).

Community development adalah proses yang mendukung individu masyarakat secara bersama-sama untuk kritis dan mengambil tindakan pada isu-isu yang penting bagi mereka, namun community development bukan merupakan aktivitas netral atau apolitis. Hal ini dapat digunakan dalam berbagai cara untuk memajukan berbagai agenda negara, pasar, sektor ketiga atau berbagai jenis kepentingan warga negara itu sendiri. Sementara tidak ada bentuk yang 'benar' untuk pengembangan masyarakat, contoh terbaik dari pengembangan masyarakat adalah mereka yang secara eksplisit membuat pengembangan masyarakat sebagai proses pembelajaran bagi demokrasi. Pengembangan masyarakat juga dibutuhkan untuk menghadapi isu-isu strategis tertentu, menjawab tantangan yang ada dalam 
globalisasi, dan mempersiapkan masyarakat yang tadinya tidak berdaya menjadi berdaya saing dalam segi ekonomi, sosial, dan politik. Gagasan pemerintah dan community development masyarakat lokal adalah secara eksplisit dan meresap dalam retorika, misi, dan kegiatan dalam berbagai upaya community development kontemporer (Chakunda \& Chakaipa 2015).

Community development merupakan kegiatan pengembangan masyarakat lokal untuk mencapai kemandirian, sehingga mencapai kondisi sosial ekonomi dan kualitas penghidupan yang lebih baik yang dilakukan oleh industri dan pemerintahan daerah. Sehingga masyarakat di tempat tersebut diharapkan menjadi lebih mandiri dengan kualitas kehidupan dan kesejahteraan yang lebih baik. Program-program community development, dapat dilakukan perusahaan atas dasar sikap dan pandangan yang umumnya telah ada (inheren) dalam dirinya, yaitu sikap dan pandangan filantropis (kedermaan).

Hubungan atau relasi antara masyarakat baik dengan korporat maupun pemerintah semakin hari semakin kompleks. Selain dinamika masyarakat terus berkembang, tantangan perusahaan dan pemerintah juga terus bertambah. Community development dipandang sebagai sarana tepat dalam membangun hubungan baik sekaligus mengurangi gangguan sosial yang timbul.

Community development berhubungan erat dengan suatu aktivitas tertentu di mana membuat masyarakat yang tadinya tidak berdaya menjadi berdaya, atau dalam konteks ini masyarakat yang tadinya tidak paham atau tidak mengetahui tentang TIK menjadi paham dan dapat memanfaatkan TIK sesuai dengan kebutuhannya masing-masing. Seperti yang dicontohkan, pelaku UKM pada mulanya diajarkan dulu dasar-dasar misalnya mengetik hingga menampilkan produknya di salah satu web online shop. Dengan adanya BLC manfaat yang diperoleh bagi penggerak UKM adalah meningkatnya pemahaman mereka dalam penggunaan TIK untuk memberikan informasi dan memasarkan produknya dalam website jual-beli online. Sudah jelas bahwa dari sebelum adanya BLC mereka tidak memiliki pengetahuan mengenai online shop dan melakukan transaksi jual beli secara konvensional maka dengan adanya bantuan dari BLC mereka dapat memperluas pangsa pasarnya melalui dunia maya.

Manfaat yang diperoleh dalam pengembangan kapasitas masyarakat melalui peranan BLC tidak hanya untuk penggerak UKM saja, akan tetapi dapat memberikan kesempatan bagi warga Kota Surabaya yang memiliki pengetahuan di bidang TIK untuk bergabung baik menjadi koordinator maupun intruktur dalam BLC. Hal ini juga membawa peluang lapangan pekerjaan baru bagi masyarakat, sehingga selain mendapatkan gaji sebagai koordinator maupun intruktur mereka juga berkesempatan untuk melakukan transfer of knowledge dibidang TIK bagi masyarakat Kota Surabaya.

Peranan BLC dalam community development sangat luas selain karena program tersebut benar-benar gratis untuk semua lapisan masyarakat, persepsi masyarakat yang selama ini menganggap bahwa BLC hanya dikhususkan bagi warga yang tidak mampu sebenarnya juga keliru. Bahkan BLC hanya untuk peserta yang mendaftar dalam pelatihan saja juga tidak tepat, dalam BLC warga bisa sekedar mampir untuk membuka email, bahkan bertanya mengenai segala hal yang berkaitan dengan internet maupun program di komputer kepada instruktur yang bertugas. Manfaat lainnya dalam program BLC berlaku tidak hanya bagi warga disekitar lokasi BLC akan tetapi bahkan masyarakat yang misalnya kehabisan paket data untuk membuka e-mail maupun internet bisa mampir untuk melakukan hal tersebut di BLC, sehingga masyarakat yang membutuhkan tidak lagi harus mengeluarkan biaya untuk pergi ke warnet.

Guna mencapai tujuan yang diinginkan dari program community development, sosialisasi memiliki peran yang penting dalam pelaksanaan program tersebut. Perusahaan merasa telah memberikan "banyak" untuk membantu masyarakat dengan kucuran dana yang tidak sedikit. Namun di sisi lain, masyarakat sekitar merasa tidak mendapat apa-apa. Berarti program yang telah dilaksanakan perusahaan tidak mencapai sasarannya. Dengan melakukan sosialisasi, komunitas diharapkan akan merasa memiliki program tersebut dan ikut bertanggung jawab terhadap pelaksanaan serta keberhasilan dari program community development tersebut. Dalam konteks BLC misalnya, sosialisasi 
terus menerus dilakukan baik melalui media online, melalui penyampaian secara struktural dari tingkat Kelurahan hingga tingkat RT.

Program BLC yang dikelola oleh Dinas Komunikasi dan Informatika Pemerintah Kota Surabaya sejauh ini sudah cukup berhasil merealisasikan tujuannya, yaitu memberikan pelatihan komputer sebagai wahana TIK kepada masyarakat warga Kota Surabaya dengan gratis. Keberhasilan ini mulai dirasakan manfaatnya oleh peserta pelatihan BLC, misalnya saja yang dulunya belum paham mengenai Program Excel kemudian setelah diajari mulai dari dasar-dasarnya menjadi mahir dalam menggunakan Excel. Kasus lain yang terjadi ada juga pada bunda-bunda Paud yang bisa memanfaatkan internet untuk memperoleh informasi yang dibutuhkan, mereka juga berperan sebagai mekanisme kontrol terhadap akses internet yang dibuka oleh anak-anak dirumahnya.

Sebagai program yang berorientasi pada pencapaian community development, BLC bersifat terbuka pada masyarakat. Artinya masyarakat bisa memilih program-program mana saja yang cocok dan sesuai dengan kebutuhan mereka. Ada yang butuh dilatih untuk memasarkan produk-produknya melalui internet, ada juga golongan masyarakat yang membutuhkan pelatihan desain untuk mengembangkan minatnya dibidang desain dengan menggunakan program-program yang ada di komputer seperti Photoshop, Corel Draw dan lain sebagainya. Selain bisa diakses oleh seluruh lapisan masyarakat, peserta pelatihan BLC juga tidak dipungut biaya dan masyarakat bisa memiliki sertifikat yang bisa digunakan sebagai bukti mahir dalam kompetensi program tertentu dengan cara mengikuti paket pelatihan yang telah disediakan serta lulus saat ujian, hal ini menandakan bahwa tujuan community development yang ingin dikembangkan tidak hanya untuk dinikmati kalangan tertentu saja tetapi bisa dirasakan manfaatnya untuk seluruh lapisan masyarakat.

Sebagai program yang berorientasi dalam meningkatkan kapasitas masyarakat, BLC sudah cukup berhasil. Hal ini ditandai dengan meningkatnya -walaupun jumlahnya tidak cukup besar- antusiasme masyarakat dalam mengikuti pelatihan dalam BLC. Peningkatan tersebut secara kuantitatif apabila dicari rata-ratanya berdasarkan Gambar 2 Data Peserta Pelatihan di BLC Tahun 2014-2015 adalah sebanyak 20,55\%. Jika dilihat pada masing-masing kelompok, maka terdapat beberapa kelompok pengguna BLC yang persentase peningkatannya cukup tinggi, yaitu dari kelompok karang taruna sebanyak $87 \%$, guru $82,47 \%$, ibu rumah tangga $80,04 \%$, pensiunan $76,97 \%$. Secara kualitatif dari hasil wawancara menunjukkan bahwa apa yang menjadi keinginan masyarakat untuk mempelajari pemanfaatan teknologi informasi dan komunikasi sudah terwujud dengan baik. Pemerintah Kota Surabaya juga sudah konsisten dalam menjalankan program BLC sebagai salah satu program unggulan dibidang e-governance, hal ini juga ditunjukkan secara konkrit melalui kualitas instruktur BLC yang jauh lebih baik dibandingkan sebelum dikelola oleh Pemkot. Kualitas instruktur ini juga mendapatkan apresiasi dari warga yang mengikuti pelatihan BLC, di mana instrukturnya bersifat responsif dan emphaty dalam melakukan pelatihan. Instruktur membimbing peserta dengan profesional dan dilakukan sesuai dengan tingkat pemahaman peserta didik.

\section{Simpulan}

BLC merupakan salah satu program yang memiliki manfaat dalam meningkatkan pemahaman masyarakat dalam bidang teknologi informasi, khususnya dalam menggunakan aplikasi yang digunakan sehari-hari seperti aplikasi perkantoran, desain grafis, dan internet. Walaupun dalam mengikuti pelatihan di BLC peserta tidak dipungut biaya dan akan mendapatkan sertifikat, akan tetapi jika dilihat berdasarkan data diferensiasi pesertanya masih belum merata. Pengguna terbanyak dalam BLC masih didominasi oleh anak-anak SD, bunda Paud, pegawai swasta, guru, dan ibu rumah tangga. Implementasi program BLC dapat dinilai berhasil, karena jika dilihat dari content of implementation dan context of implementation sudah terpenuhi, akan tetapi memang keberhasilan program BLC tidak dapat langsung dirasakan manfaatnya saat ini, walaupun partisipasi warga masyarakat meningkat.

Program BLC diorientasikan untuk menjawab tantangan pemanfaatan TIK disegala bidang, di mana e-governance menjadi suatu isu global yang tidak dapat dielakkan. Dalam upaya tersebut pemerintah merintis kerja sama dengan PT. Telkom Indonesia untuk memberikan dukungan bagi warga 
masyarakat dalam pemberian pendidikan informal dibidang TIK. Karena program BLC ini sebagai langkah awal dalam community development, sehingga tujuan agar masyarakat memahami dan dapat memanfaatkan TIK baik dalam pemanfaatan pelayanan publik, mendukung aktivitas pekerjaan seharihari, sosialisasi dan transfer knowledge pada bidang segala bidang, dan manfaat ekonomi di mana masyarakat atau UKM dapat melakukan jual beli secara online melalui fasilitas internet.

\section{Daftar Pustaka}

Bedi K, Singh PJ, \& Srivastava S (2001) Government net: New governance opportunities for India. SAGE Publications Pvt. Limited.

Chakunda V \& Chakaipa S (2015) Local government capacity building and development: Lessons, challenges and opportunities. Political Sciences and Public Affairs 3(1):149.

Grindle MS (1980) Politics and Policy Implementation in The Third World. New Jersey: Princeton University Press.

Holmes D (2001) eGov: eBusiness strategies for government. Nicholas Brealey Publishing.

Ndraha T (1990) Pembangunan Masyarakat Tinggal Landas. Jakarta: Penerbit Rineka Cipta.

Palvia SCJ \& Sharma SS (2007) E-Government and e-Governance: Definitions/Domain Framework and Status around the World. India: Computer Society of India.

Sharma SK (2004) Assessing e-government implementations. Electronic Government Journal 1(2):198-212.

Sharma SK (2006) An E-government Services Framework. In: Khosrow-Pour M (ed) Encyclopedia of Commerce, E-Government and Mobile Commerce. USA:Information Resources Management Association, Idea Group Reference:373-378.

Sharma SK \& Gupta JND (2003) Building blocks of an e-government-a framework. Journal of Electronic Commerce in Organizations 1(4):34-48.

Tapscott D (1998) Growing up Digital: The Rise of the Net Generation. New York: McGraw Hill. 